DOI https://doi.org/10.36059/978-966-397-181-0/1-15

\title{
THEORIES OF THE FAULT OF THE STATE IN INTERNATIONAL LAW
}

\section{Andreichenko S. S.}

\section{INTRODUCTION}

The intensification of the global processes of globalization, which characterize the current trends in the development of legal life, pose new challenges to researchers, in solving which they will always turn, on the one hand, to the development of legal ideas, on the other-to offer new ones, comparing different positions and developing optimal solutions. As Mr. Galet puts it, "questions raised by circumstances always require a solution, or at least an answer". One such legal concept, the application of which requires hasty answers, is "guilt". The increased interest in the category of "guilt" is explained by its importance in the system of philosophical, social and legal values. The principle of responsibility for guilt has long been defended by humanistic human thought and gradually found reflection in the legal systems of society. With the development of civilization, when human life and individual freedoms acquired the highest value, the question of" guilt " becomes Central to the system of legal reality. The category of guilt is one of the Central and important international responsibility.

It is necessary to agree with the position of A. M. Talalaev, stated in the review of the monograph by D. B. Levin's "Responsibility of States in modern international law" (1966): "One can argue whether there is such a concept in international law itself as a set of legal norms, whether there is a mandatory prerequisite for international legal responsibility of the state, but the fact that this concept exists in the theory of international law is a fact that was confirmed during the discussion of the question of responsibility in the UN international law Commission. Moreover, this concept is perhaps Central to the doctrine of the international legal responsibility of States".

A witty example is given by A. Gattini in an article on the place of guilt in the ILC articles on state responsibility "Smoking or not Smoking: some observations on the actual place of guilt in the ILC Articles on state responsibility" (1999): Jagota, a former member of the ILC, referring to the place of guilt in the Draft articles on state responsibility, remarked: "It's like when you walk into a room and you can say that someone has just smoked a cigarette. You can't see the smoker, but you know he's there". 
Having analyzed the theoretical developments and jurisprudence on the fault of the state in international law, we can identify the following main approaches to its essence: the theory of subjective responsibility (fault responsibility), the theory of objective responsibility (objective responsibility), an eclectic approach to the question of guilt.

\section{The theory of fault responsibility}

According to the theory of subjective responsibility, guilt is a prerequisite for the emergence of international responsibility. Supporters of the allocation of guilt proceed from the fact that the state shows its will.

The need for guilt as one of the important elements of an international offense is recognized by many representatives of the international legal doctrine, despite the different approaches of each of them to the problem of guilt and guilt: G. ago, D. B. Levin, G. I. Tunkin, Y. M. Kolosov, J.-P. Queneudec, V. A. Vasilenko, L. Oppenheim, G. Lauterpacht, A. Verdross, C. Sepulveda,A. Navarro, A. Ross, E. Menzel, A. Hershey, M. Krol, and others.

The assertion that the guilt of the offending state is a necessary condition for the characterization of her conduct as internationally wrongful has traditionally prevailed in the doctrine of international law since the time of Grotius. In the XIX century., imitating G. Grotius, lawyers took the Roman principle as the basis of responsibility in international law. The corresponding concept was quite popular in the future.

Most Soviet lawyers defended the concept of guilty state responsibility for international offenses. The support of a number of the most prominent Soviet international lawyers for the concept of guilty state responsibility is primarily due to the importance that the Soviet doctrine of international law gave to responsibility for international crimes. Speaking in support of the inclusion of animus in the definition of aggression, the Soviet representative to the UN Special Committee on the definition of aggression noted that aggression is a serious international crime and the responsibility of the aggressor is directly determined by its intention .

It is worth noting that guilt as a mandatory element of an international wrongful act is also provided for in certain cases by international treaties. In particular, according to part 2. article 56 IV of the Convention on the laws and customs of land war of 1907," any intentional seizure, destruction or damage to such institutions, historical monuments, works of art and science is prohibited and shall be subject to prosecution". Article 2 of the Convention on the prevention and punishment of the crime of genocide of 1948 States: “... genocide means any of the following acts committed with intent ..." that is, we are talking about guilt in the form of direct intent. The 
term "genocide", writes Professor N. A. Zelinskaya, etymologically associated with two languages (in Greek: "genos" - "genos" and in Latin: "caedo" - "kill") and combines two characteristics, one of which is associated with the definition of the victim, and the other - with the purpose of the offender. The international court of justice notes that an essential characteristic of genocide is the deliberate destruction of national, ethnic, racial or religious groups.

Various arguments were put forward in favor of the theory of guilt. Thus, the proponents of the theory of guilt strongly rejected the argument of the representatives of the objective theory that the question of attribution to the state of the behavior of its organs can be left to the consideration of national law. In their view, such attribution depends directly on international legal norms. Such rules may provide for the guilt of officials as a necessary prerequisite for attributing an internationally wrongful act to a state, and the conduct of public authorities will be considered unlawful, regardless of the fact that such conduct is considered lawful and even mandatory under the national law of the state concerned.

Another argument in favour of the theory of guilt is the fact that it would be unfair to attribute to a state those acts or omissions that were committed without fault on their part by individual perpetrators and to qualify the acts as internationally wrongful.

The theory of guilt is taken into account by international arbitration and judicial bodies. It is customary to refer to the 1920 Home Missionary society claim between great Britain and the United States to illustrate the theory of subjective responsibility. In this case, the imposition of the "hut tax" on the protectorate over Sierra Leone provoked a local uprising, which damaged the property of the missionary Association and killed missionaries. The Tribunal rejected the claim of the missionary Association (represented by the United States) and noted that "there is a well-established principle in international law that a government cannot be held accountable for acts of rebel groups committed contrary to the actions of the authorities, in cases where the government is not guilty of violations or lack of good faith in suppressing the rebellion" (more details on the attribution to the state of the conduct of rebel movements will be discussed in Chapter 2).

Another example of an illustration of guilt theory is the Corfu channel case (1949). The case concerned the laying of mines by private actors in Albanian coastal waters. The court had to determine, from the point of view of the law, the legal obligations of Albania arising from its control over the territory. Taking into account that Albania knew about the mining, the UN IPU considered it not to prevent, as a violation of international law as a result of inaction. The court held that each state had an obligation "not to 
knowingly permit its territory to be used for acts contrary to the rights of other States".

In the Corfu Channel case, the international court of Justice tended to apply the theory of guilt, noting that the mere fact that mines were planted in Albanian waters did not entail prima facie liability and did not obviate the need for evidence.

The approach taken in the Corfu Strait case, in turn, is difficult to reconcile with the approach taken in the Case concerning United States Diplomatic and Consular Staff in Tehran (1980), when Iranian public authorities were aware of the unlawful conduct of individuals and did not take any action. The topic of guilt, however, was not addressed in the UNIC. This may have been because the exact role of the state was unclear and providing evidence would have caused almost insurmountable problems .

The element of intent enshrined in the norm that prohibits genocide was addressed in the ICJ Decision on the application of the Convention on the prevention and punishment of the crime of genocide of 26 February 2007 (Bosnia and Herzegovina V. Serbia and Montenegro) . On January 9, 1992, the Serbian Republic of Bosnia and Herzegovina declared independence. On March 6, 1992, Bosnia and Herzegovina itself officially declared its independence. In the period 1992-1995, an armed conflict between Bosnian Serbs and Bosnian Muslims took place in the territory of this state. Bosnian Serbs were supported by Serbia and Montenegro, against which 1993 Bosnia and Herzegovina brought charges of genocide.

The court found that genocide presupposes intent and special intent (dolus specialis): "it is not Enough that members of a group are targeted because they belong to that group, that is, because of the discriminatory intent of the perpetrator. In addition, it is necessary that the acts listed in article II were committed with the intention to destroy, in whole or in part, this group as such". The court established the fact of Commission of the acts provided by art. II, however, did not detect the existence of a specific intention to destroy the group as such and noted that the acts concerned could be war crimes and crimes against humanity, which it was not competent to consider.

This intention was established by the Court only when considering the incident in Srebrenica, where in July 1995 Bosnian Serbs killed more than seven thousand Bosnian Muslims. These actions were qualified as acts of genocide, however, the Court recognized that they could not be blamed on Serbia and Montenegro. The court found that the Respondent state had failed to fulfil its obligation to prevent genocide because, while it had the capacity to influence Bosnian Serbs, it had done nothing to prevent the Srebrenica massacre. The court also found that the Respondent state had failed to 
comply with its obligation to cooperate with the Yugoslavia Tribunal, which follows from article VI of the Convention, since it had failed to take appropriate measures to search for, detain and place at the disposal of the Tribunal General G. Mladic, who was being prosecuted for committing acts of genocide.

In decisions on the use of force against Yugoslavia, the Court rejected that country's reference to the genocide Convention, inter alia, on the grounds that the bombing did not in fact include an element of group intent, as required by the genocide Convention .

On the basis of the analyzed doctrine and practice of international law, it can be concluded that guilt can be a necessary element of an internationally wrongful act, but only in specific cases, namely, if it is provided for by specific rules of international law. This position is supported by such

authoritative scientists as D. Levy,I. Brownlie,E. Aréchaga, P. M. Kuris and others.

\section{Theory of strict liability}

Since the beginning of the XX century, some authors have tried to understand the role of guilt in the origin of international legal responsibility of the state in a different way. As A. Verdross (1959) noted, "in the past, the science of international law considered it certain that responsibility for an international offense arises for a state only if the act is committed or the omission is committed by a state organ is guilty; there is currently a divergence on the question of how such a subjective factor can have significance in international law".

According to the objective theory, the famous representatives of which were D. Anzilotti, E. Aréchaga, M. Bourquin,E. Borchard, C. Eagleton, J. Combacau, I. I. Lukashuk, J. P. Monnier, D. P. O'Connel, P. Okowa, S. Olleson,N. Politis, J. Starke et al., the act of a state is qualified as internationally wrongful as a result of a breach of an international obligation by state organs, that is, only the objective conduct of the organ by which the international obligation is breached is relevant.

Proponents of the theory of objective responsibility insist that the theory of culpable responsibility looks like a "real anachronism", that "the very nature of international law precludes the possibility of considering guilt as the basis of interstate responsibility".

In the international legal literature there is a considerable amount of arguments in support of the objective theory of international responsibility of the state.

One such argument is the absence of a single concept of guilt within the domestic legal systems of States. International arbitrations and courts also 
refrain from applying the concept of "fault" in cases of international responsibility of States.

Some of the arguments are related to the idea that attribution of a wrongful act to the state is a legal operation-an imputation-which is directly or indirectly carried out according to national legal norms. Proponents of the objective theory believe that according to the national legal order, the state can be assigned only the authority's responsibility, which is carried out within the competence of the authority and in accordance with the current legislation.

Opponents of taking into account the element of guilt in the imposition of international legal responsibility often cite the following argument: "the requirement of establishing guilt gives the delinquent state the opportunity to challenge the legality of imposing responsibility on it (which it bears from the moment of the tort) by reference to the absence or unproven intent or negligence on the part of its organs". This fact is pointed out by G. Palmisano : "in this context, the problem is also the extreme difficulty of proving intent to act unlawfully, if the act is committed by a large number of different bodies. This would clearly cause confusion in the area of state responsibility, to the detriment of the principle of legal certainty in international relations".

I. Brownlie pointed out that "in their practice, States, arbitral tribunals and the international court of Justice have followed the theory of objective responsibility as a General principle, which in some cases may be modified or not applied".

Let us turn to some of these cases. For example, in the case of the Union Bridge Company (United States) v. Great Britain, which dealt with English mistakes of an employee in respect of supplies of materials for the construction of a bridge (they were neutral property) and their purpose (they were intended for conventional, not the railway bridge) and the transfer of materials to the disposal of the Imperial Railways, the court established the liability of great Britain, noting that "it does not depend on the fact that an English clerk made a mistake regarding the identity and destination of the materials, as well as the fact that the British authorities did not intend to assign them".

The state may be held liable "without fault" for the actions of officials not only in cases where they directly exceed the authority to violate orders, but even in cases where such officials are in good faith mistaken. In Jesse Lewis (United States) v. Great Britain (David J. Adams case) (1921), the arbitration held that each government must be held accountable to others for errors in the decisions of its officials who acted within their authority and were empowered to enforce their claims . 
In Thomas H. Youmans (U. S. A.) v. United Mexican States (1926), the claims Commission also raised the issue of guilt. The case concerned the failure of the Mexican government to protect foreigners from the fury of the mob. In its decision, the Commission succinctly stated that the "lack of diligence" on the part of Mexico for the protection of aliens is important for the introduction of state responsibility. However, the exact role of guilt remained unclear. In the Trail Smelter award (1938), concerning harmful emissions into the atmosphere by a steel plant that caused damage to the United States, Canada should have been liable on the grounds that it had breached its obligation not to allow its territory to be used in a way that did not cause damage to the territory or in the territory of another state. Possible exculpatory circumstances were not taken into account by the court, and the question of guilt was not considered.

In the case of Neer Claim (1926), which concerned the murder of an American overseer in the mines of Mexico, the United States, on behalf of the widow and daughter of the deceased, sought damages due to the lack of thoroughness in the investigation by the Mexican authorities. The General Commission for the review of mutual claims rejected the claims by applying an objective criterion.

Well-known experts in the field of international law, in particular, Malcolm N. Shaw,M. Akehurst, A. Cassese and others, have repeatedly noted that the practice of the International court of justice in the vast majority of cases corresponds to the concept of objective responsibility, so the issue requiring proof in the process of recognition of the state responsible for certain actions, is to establish the necessary connection between the state and the person or persons who directly committed an internationally wrongful act.

As for the position of the UN international law Commission, this body did not include the element of state guilt in the draft articles on state responsibility in 1980, 1996 or 2001, thus avoiding difficulties in resolving the question of the presumption of guilt or innocence of the state and the problem of proof of guilt. This approach of the Commission was objected to in the comments of some governments on the articles of the first part of the draft (for example, the government of Austria). The Commission's position has also attracted much criticism in the literature, although some international law experts have supported this decision.

I. I. Lukashuk also pointed out the dominance of the concept of objective responsibility. According to the scientist, this trend is determined both by the nature of international law and the need to improve the level of international legality. Therefore, objective responsibility naturally found its way into the 
articles on state responsibility, starting with the principle of responsibility itself.

Apparently, the principle of objective responsibility has every reason to be considered a universal principle. It provides a solid basis for the maintenance of normal standards in international relations and for the establishment of the principle of reparation, - concluded I. Brownlie.

All this allows us to conclude that the principle of objective responsibility is firmly entrenched in modern international law, which is confirmed by the relevant developments of scientists and decisions of international judicial institutions.

At the same time, in the Western international legal literature, there are increasingly statements in the sense that neither the theory of culpable responsibility nor the theory of objective responsibility can independently point to the actual grounds of international legal responsibility. For example, $R$. Luzzatto considered it necessary to abandon the attempt to find a single answer to the question on what is the basis of responsibility arising in international law in all possible cases and noted that the solution of the problem of guilt is possible only "on the basis of practice" .

With regard to international judicial and arbitration practice, it provides many examples where decisions were based both on the fault of the state and on an objective violation of international law.

Moreover, there are numerous cases when one and the same arbitral award is indicated by some authors to confirm one theory, and by others the second. As a possible solution to the question of state responsibility in a particular case, the doctrine of international law proposes the use of the so-called eclectic approach to the concept of guilt, which will be the subject of the next paragraph.

\section{Eclectic approach to the issue of state guilt}

In the XX century. the whole history of the theory of international legal responsibility of the state was marked by the struggle between the proponents of the theories of guilty responsibility and objective responsibility.

O. Diggelmann, describing the debate over the" nature " of state responsibility that has been going on in the legal literature for several decades, rightly observes that "it was an ideological debate that took a lot of energy from the authors and speakers on this topic. The discussion of the" nature "of state responsibility was an abstract dispute in which fundamental positions depended heavily on ideological beliefs that are difficult to prove. Therefore, the approach of the ILC gave hope that it was finally possible to overcome the long-standing dispute". The approach of the international law 
Commission undoubtedly ended the discussion, since the topic of guilt no longer concerned secondary norms. These rules contain only a few hidden references to subjective elements-mainly in the articles dealing with force majeure (article 23), disaster (article 24) and necessity (article 25) in the Chapter on "Circumstances precluding wrongfulness". They do not, however, contain any General rules as to mental requirements.

At the same time, the discussion of guilt reappears in disputes arising in the context of the interpretation of primary norms.

Given that the existing classical theory about wine - the theory of objective responsibility theory the subjective responsibility - do not provide solutions to all issues related to the fault in the sphere of international responsibility, a large part of the modern doctrine, in particular K. Zemánek, I.Brownlie, P.Dupuy, B. Graefrath, prefer an eclectic approach to the problem of guilt in international law. This approach is based on the specific content of the primary rules that have been violated by an internationally wrongful act, rather than secondary rules that define in General terms the elements and conditions of responsibility of States for wrongful acts.

An eclectic approach on the part of the state was laid out in the ILC commentary to Articles on responsibility of States for internationally wrongful acts of 2001, the ILC has avoided a clear decision on fault in the norms on the elements of an internationally wrongful act (article 2 Articles), and the rules on attribution of conduct to a state (articles 4-11 of the Articles). However, in the commentary to article 2, the ILC explained: "the attribution Element is often described as 'subjective' and the excitation element as 'objective', but such terminology is avoided in the Articles. The answer to the question of whether there is a violation of any rule may depend on the intention or knowledge of the relevant public authorities or agents and in this sense may be "subjective"... In other cases, the criterion of finding a breach of an obligation may be "objective" in that attention or inattention on the part of the relevant public authorities or agents may not be relevant to the case. Whether the liability is "objective" or "subjective" in this sense depends on the circumstances, including the content of the primary obligation in question. ... This is also true for other criteria, whether they involve some degree of infringement, fault, negligence or failure to exercise due diligence. They vary depending on the circumstances for reasons that are ultimately related to the object and purpose of the contractual provision or other rule that underlies the primary obligation. The Articles do not establish any presumption as to the various possible criteria. It is a matter of interpretation and application of the primary rules violated in each case". (Commentary to article 2 (3) of the Articles). 
When speaking about the interpretation of primary obligations, it is necessary to focus on the distinction between primary and secondary rules of international law, because the Articles on state responsibility of 2001 are based on the fundamental distinction between "primary" and "secondary" rules on state responsibility.

Primary norms directly regulate the behavior of subjects. Secondary rules determine the consequences of non-performance of obligations arising from primary rules. This division is close to the division of norms into material and procedural. However, it is not identical to it, which was emphasized by the special Rapporteur R. Ago, who introduced this division. His report said it was "not just procedural rules". The articles on responsibility are devoted to the latter. The Commission sought to avoid delving into the definition and codification of the primary rules whose violation gave rise to liability.

The United Nations international law Commission, in preparing the draft articles on state responsibility for offences, concluded at its twenty-fifth session that it was necessary to focus on the study of the rules governing responsibility and to draw a clear distinction between that task and the task of establishing "primary" rules that imposed on States an obligation whose violation might entail responsibility. At the XXVIII session of the UN General Assembly, a significant number of representatives in the Sixth Committee endorsed the Commission's intention to focus on the study of "secondary" rules, which determine the legal consequences of nonperformance of obligations under the "primary" rules.

Primary and secondary rules are inseparable, interrelated and complement each other in consolidating the international legal order. The content of the obligations enshrined in the primary rules cannot be disregarded in determining the content and consequences of the offence.

At the same time, the distinction between primary and secondary norms has its critics. For example, the first report of J. Crawford argued that "secondary" rules are a mere abstraction and have no practical utility; that the assumption that there are generally accepted secondary rules does not take into account the possibility that specific substantive rules, or substantive rules in a particular branch of international law, may become the source of their own special secondary rules, and that the draft articles themselves do not make this distinction consistently, indicating its artificial nature .

It should be emphasized that, in practice, the distinction between primary and secondary rules has a number of advantages. It is impossible not to agree with special Rapporteur J. Crawford, that such a distinction allows for the revision and development of some General rules on liability, without the need to address many questions about the content or application of specific rules, the violation of which may entail liability. For example, the question 
of whether a state is liable in the absence of harm or loss to another state or States was discussed in detail. If harm is understood as losses expressed in monetary valuation, it is quite clear that it is not always necessary. However, there are certain situations where there is no legal harm to another state if it has not suffered material damage. This position varies depending on the material or primary norm in question. It is only necessary to formulate the draft articles in such a way that they provide for different possibilities depending on the primary rule applied .

J. Crawford specifically emphasizes the issue of guilt: "a similar analytical method could be used in relation to the question of whether a certain 'psychic element', or culpa, is necessary for state responsibility to occur, or whether state responsibility is 'strict' or even 'absolute', or whether it depends on 'due diligence'.

Thus, the absence of the requirement that there is an element of state guilt to establish an internationally wrongful act in the Articles on state responsibility does not mean that there is no such element in the legal rules on state responsibility. Rather, - as writes J. Crawford, - this reflects the important point that different primary rules on international responsibility may set different standards of fault ranging from "due diligence" to "strict liability".

Despite the existing controversies, the literature argues that the eclectic approach is generally acceptable, but at the same time its individual provisions are either insufficient or subject to criticism . Due to the lack of consensus among the authors, there are reasonable doubts that the eclectic theory can have the same meaning as the theory of objective responsibility and the theory of subjective responsibility .

Thus, the approach according to which the question of guilt is made dependent on the interpretation of primary rules, along with the advantages, has its drawbacks, associated primarily with the complexity of the monotonous interpretation of the primary rules of international law, the lack of unanimity among scientists and practitioners.

\section{CONCLUSIONS}

The articles on state responsibility of 2001 do not establish the content of obligations under a specific primary norm, do not contain their interpretation, do not answer the question of the duration of the obligation for States. The purpose of these Articles is to formulate the basic rules of international law with regard to the responsibility of States for internationally wrongful acts, namely the General conditions under which a state is responsible for the breach of its obligations, as well as the legal 
consequences arising from such responsibility, i.e. the focus is on secondary rules of international law on state responsibility.

In order to deal in practice with the question of state responsibility for the presence or absence of such an element of the composition of an internationally wrongful act as "guilt", it is important, inter alia, to properly interpret the relevant primary obligations of a particular state. In this aspect, interpretation is undoubtedly one of the key points of theory and practice in the field of international responsibility. In fact, the correctness of the application of international norms depends on interpretation and, accordingly, the effectiveness of the system of international law as a whole largely depends on its effectiveness. Interpretation is one of the necessary tools to ensure the functioning of the international legal system.

The classical theories of fault responsibility and objective responsibility (the struggle between the proponents of which marked the entire history of the development of the theory of international legal responsibility of the state in the XX century) alone are not able to point to the actual grounds of international legal responsibility. As a possible solution to the question of state responsibility in a particular case, the doctrine of international law proposes an eclectic approach to the understanding of state guilt, based on the specific content of the primary rules that have been violated by an internationally wrongful act, rather than secondary rules that define in General terms the elements and conditions of state responsibility for wrongful acts. This compromise approach has led to discussions about state guilt in the context of the interpretation of the primary rules of international law.

\section{SUMMARY}

Since the beginning of the XX century, attempts have begun to rethink the role of guilt in the establishment of international responsibility of the state. Gradually appeared more and more supporters of the theory of objective responsibility. The concept of objective responsibility is of paramount importance in modern international legal doctrine and is confirmed by the practice of international courts and arbitrations, which prefer not to deal with the problem of guilt.

The classical theories of fault responsibility and objective responsibility (the struggle between the proponents of which marked the entire history of the development of the theory of international legal responsibility of the state in the XX century) alone are not able to point to the actual grounds of international legal responsibility. As a possible solution to the question of state responsibility in a particular case, the doctrine of international law proposes an eclectic approach to the understanding of state guilt, based on the specific content of the primary rules that have been violated by an 
internationally wrongful act, rather than secondary rules that define in General terms the elements and conditions of state responsibility for wrongful acts.

\section{REFERENCES}

1. Application of the Convention on the Prevention and Punishment of the Crime of Genocide (Bosnia and Herzegovina v. Serbia and Montenegro). Judgment of 26 February 2007 // ICJ Reports. 2007.

2. Application of the Convention on the Prevention and Punishment of the Crime of Genocide (Bosnia and Herzegovina v. Serbia and Montenegro) Judgment of 26 February 2007 // ICJ Reports. 2007.

3. Commentaries to the draft articles on Responsibility of States for internationally wrongful acts adopted by the International Law Commission at its fifty-third session (2001). Report of the Commission to the General Assembly on the work of its fifty-third session // Yearbook of the International Law Commission. 2001. Vol. II, Part Two.

4. Diggelmann O. Fault in the Law of State Responsibility : Pragmatism ad infinitum ?German Yearbook of International Law. 2006. Vol. 49.

5. First report on State Responsibility by Mr. James Crawford / International Law Commission. Fiftieth session. Geneva, 20 April - 12 June 1998. New York, 27 July - 14 August 1998. Para. 14. UN Doc. A/CN.4/490.

6. First report on State Responsibility by Mr. James Crawford / International Law Commission. Fiftieth session. Geneva, 20 April -12 June 1998. New York, 27 July - 14 August 1998. Para. 16. UN Doc. A/CN.4/490.

7. Flemme M. Due Diligence in International Law.Master thesis, 2004.

8. Gattini A. Smoking / No Smoking: Some Remarks on the Current Place of Fault in the ILC Draft Articles on State Responsibility. European Journal of International Law. 1999. Vol. 10.

9. Home Frontier and Foreign Missionary Society of the United Brethren in Christ (United States) v. Great Britain, 18 December 1920 // Reports of International Arbitral Awards. Vol. VI.

10. Jesse Lewis (United States) v. Great Britain (David J. Adams case) (1921) // Reports of International Arbitral Awards. Vol. VI.

11. L. F. H. Neer and Pauline Neer (U. S. A.) v. United Mexican States (1926) // Reports of International Arbitral Awards. Vol. IV.

12. Luzzatto R. Responsabilità e colpa in diritto internazionale R. Luzzatto // Rivista di diritto internazionale. - Milano, 1968. Vol. Ll, fasc. 1.

13. Palmisano G. Fault . Max Planck Encyclopedia of Public International Law. Vol. III. 
14. Pisillo-Mazzeschi R. The Due Diligence Rule and the Nature of the International Responsibility of States. German Yearbook of International Law. Vol. 35. 1992.

15. Report of the International Law Commission on the work of its twenty-fifth session, 7 May - 13 July 1973. UN Doc. A/9010/Rev.1 Official Records of the General Assembly. Twenty-eighth session. Supplement № 10 // Extract from the Yearbook of the International Law Commission. 1973. Vol. II.

16. The Corfu Channel case (United Kingdom v. Albania). Judgment of 9 April 1949 // ICJ Reports. 1949.

17. homas H. Youmans (U.S.A.) v. United Mexican States (1926) // Reports of International Arbitral Awards. Vol. IV.

18. Trail Smelter Arbitration (United States of America v. Canada) (1938) // Reports of International Arbitral Awards. Vol. III.

19. Union Bridge Company (United States) v. Great Britain ) (1924) // Reports of International Arbitral Awards. Vol. VI. P.

20. United States Diplomatic and Consular Staff in Tehran (United States of America v. Iran). Judgment of 24 May 1980 // ICJ Reports 1980.

21. Lake Lanoux Arbitration (France v. Spain) (1957) // Reports of International Arbitral Awards. Vol. XII.

22. Елынычев В. Н. Вина в международном праве. Советское государство и право. 1972. № 3.

23. Зелінська Н. А. Міжнародно-правова концепція міжнародного злочину : дис. ... доктора юрид. наук : 12.00.11, 2006.

24. Кроуфорд Д. Статьи об ответственности государств за международно-противоправные деяния. United Nations Audiovisual Library of International Law. URL: www.un.org/law/avl.

25. Курис П. М. Международные правонарушения и ответственность государства. Вильнюс : Минтис, 1973.

26. Лукашук И. И. Право международной ответственности. М. : Волтерс Клувер, 2004.

27. Международное право. В 2-х книгах: перевод с английского. Кн. 2 / Броунли Я. ; под ред. : Тункин Г. И. ; пер. : Андрианов С. Н. М. : Прогресс, 1977.

28. Международное право. В 2-х книгах : перевод с английского. Кн. 2 / Броунли Я. ; под ред. : Тункин Г. И. ; пер. : Андрианов С. Н. М. : Прогресс, 1977.

29. Международное право. Изложиль Де Галетъ.Санктпетербургъ, 1860. (Предисловие). 
30. Международное право. Перевод с немецкого; под ред. : Тункин Г. И. (Предисл.) ; пер. : Кублицкий Ф. А., Нарышкина Р. Л. М. : Иностр. лит., 1959.

31. Талалаев А. Н. Д. Б. Левин. Ответственность государств в современном международном праве. М. : Международные отношения, 1966. 152 с. : [Рецензия]. Правоведение. 1967. № 2.

\section{Information about the author:} Andreichenko S. S.,

Doctor of Sciences in Law, Associate Professor, Professor at the Department of International Law and Comparative law, International Humanitarian University 33, Fontanska Road str., Odessa, 65009, Ukraine 